\title{
Modeling riverbank stability and potential risk to development in the Penobscot River estuary of Maine, USA
}

\author{
N. A. Briggs, R. Freeman, S. LaRochelle, H. Theriault, \\ R. J. Lilieholm \& C. S. Cronan \\ University of Maine, Orono, Maine 04469-5755, USA
}

\begin{abstract}
The Penobscot River Watershed drains nearly one-quarter of the State of Maine $\left(23,180 \mathrm{~km}^{2}\right)$. The River's estuary stretches $40-\mathrm{km}$, from the fall line at presentday Bangor, to the Penobscot Bay along Maine's rugged "Downeast" Atlantic coast. This lower stretch of the River, along with much of coastal Maine, is experiencing increased development pressures and was recently ranked first in the Nation in the amount of forestland at risk from future development. Within this region, shorelands are at greatest risk due to ready access and high amenity values. Such development poses significant risks to a wide range of ecosystem services and is in turn at risk from unstable shorelands and bank erosion. Maine's 1971 Shoreland Zoning Act restricts land use, vegetation management, and the location of structures within shoreland zones. The law's effectiveness, however, is oftentimes compromised by its implementation at the municipal level, where resources and expertise are limited. This paper develops a logistic regression model of bank stability for a $15.2-\mathrm{km}$ section of the River's estuary based on natural and regulatory variables (i.e., current land cover, land use, vegetation type and density, and structure setback). Results indicate that bank stability is positively correlated with greater structure setbacks and increased vegetation density and size along the riverbank. Model predictions suggest that $24 \%$ to $92 \%$ of the riverbank is at risk of increased erosion from future development. These predictions are then used to evaluate the effectiveness of existing land use ordinances under current and future development scenarios particularly with regard to structure setbacks and vegetation removal guidelines.
\end{abstract}

Keywords: ecosystem services, erosion, logistic regression, shorelands, structural setbacks, urbanization, wetlands. 


\section{Introduction}

Maine's Lower Penobscot River watershed is expected to face intense development pressures over the next 20 years (Stein et al. [11]). The watershed, comprised of mostly forests and wetlands with scattered farming communities and urban centers, provides a host of valuable economic, social, and ecosystem services to the region and State. Although the watershed is sparsely populated today, residents migrating to Maine as well as those seeking second or seasonal homes are rapidly spreading low density residential development throughout the region (White [13]; Stein et al. [11]).

Within the watershed, areas with high amenity values such as shorelands are experiencing intense development pressures. Such development can compromise bank stability and lead to increased erosion and reduced ecosystem function. In turn, this instability places development at risk from bank movement and collapse (Maene and Wan Sulaiman [5]; Pimentel and Kounang [9]; Ott [8]). Shoreland properties command high real estate values and often attract significant investment in homes and related structures. As a result, these lands not only raise considerable tax revenues for local municipalities, but also present the potential for significant loss of life and property in the event of shoreland erosion and slope failure.

The 1971 Maine Shoreland Zoning Act was enacted in response to growing concerns over the impacts of land use and development along riparian corridors. The Act addresses lands adjacent to great ponds (ponds greater than 4 ha in size), rivers, streams, ocean coasts, and wetlands, with the intent to protect water quality and natural habitat, control and prevent water pollution, and maintain the health of freshwater and coastal wetlands. The Act also seeks to protect public and private property and investment from degradation and damage due to shoreland erosion (Maine BLWQ [6]).

Protection under the Act is provided through development and land use regulations, structure setbacks, conservation of vegetative cover, and erosion and sedimentation control (Maine BLWQ [6]). The desire to direct growth away from ecologically sensitive shorelands requires that decision makers regulate the location of new structures within riparian zones. Building setback regulations and vegetation removal restrictions are common methods to balance river protection and land use by restricting construction and landowner activities in locations likely to experience increased erosion.

The Act is implemented and enforced by local municipalities - a feature that commonly weakens the law's effectiveness when towns develop ordinances with insufficient protection. In addition, the resources and commitment of local communities - including that of local enforcement officials - varies considerably throughout the State and oftentimes leads to inconsistent implementation of the law.

In an effort to reduce economic, social, and ecological losses from future development and changing land use, this paper demonstrates how communities can survey local shorelands to assess erosion risk and improve town ordinances based on the relationships between biophysical and socioeconomic factors. 
The objectives of this paper are to: (1) identify and map bank stability along the Penobscot River in Orrington, Maine; (2) establish a set of influential factors and model their relationship to bank stability; (3) estimate areas of future instability likely to result from increased development; and (4) evaluate the effectiveness of Orrington's municipal land use ordinance with respect to structure setbacks and vegetation removal guidelines.

\section{Study area}

The Town of Orrington (population 3,627) is located $15 \mathrm{~km}$ south of Bangor along the tidal, brackish lower reaches of the Penobscot River estuary (Figure 1). The River forms the Town's western boundary for $15.2 \mathrm{~km}$ and is valued for both residential and commercial development. Orrington is primarily a rural community, with development concentrated along the banks of the River and an inland lake. Many residents rely on Bangor - Maine's third-largest city with a population of 31,550 - for both jobs and services (Orrington Comprehensive Plan [7]). Orrington's median household income in 2000 was $\$ 44,327$ (US Bureau of Census [12]).

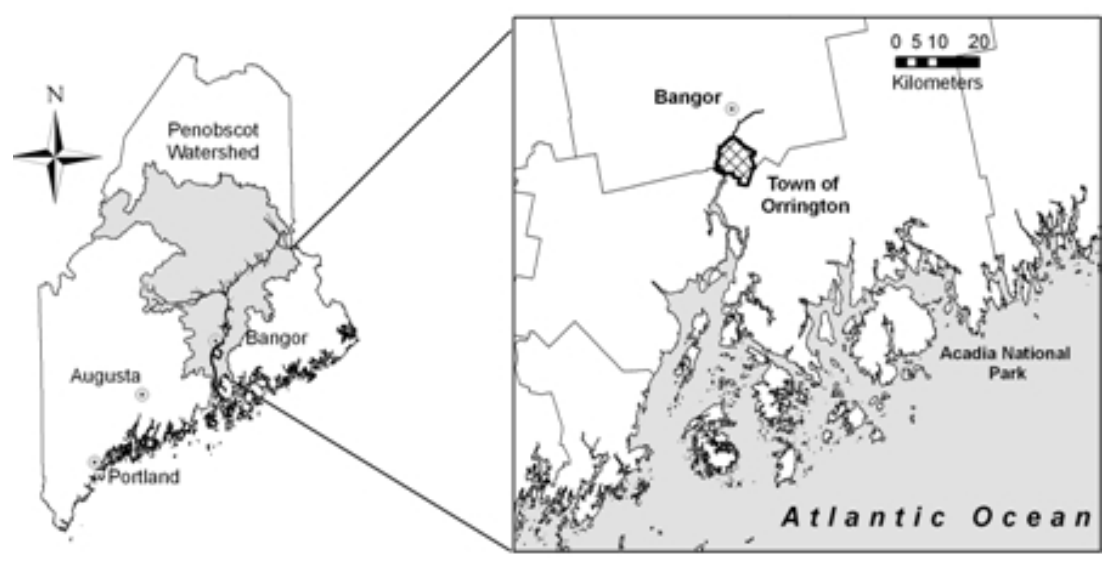

Figure 1: $\quad$ State of Maine with town of Orrington study site (inset).

\section{Methods}

A water-based survey was used to map bluffs along Orrington's Penobscot River shoreline by collecting data describing current bank stability, as well as environmental and human factors thought to influence stability (Kelley and Dickinson [4]). Current stability, bluff material, vegetation type and density, as well as proximity of nearest structure and percent developed land within $100 \mathrm{~m}$ were collected to reflect baseline stability. These data were entered into a GIS as $10 \mathrm{~m}$ segments, resulting in 1,523 observations used as input for a logistic regression statistical model. The logistic model was developed to identify 
attributes of the bank and surrounding area that were correlated with stability based on earlier studies (Winterbottom and Gilvear [14]; Bledsoe and Watson [2]; Atkinson et al. [1]), and by including variables related to shoreland zoning, including estimates of setback distances and vegetation clearing. A binary logit model was used to estimate the probability of a stable section of riverbank as related to the variables. For $k$ explanatory variables, the model is as follows:

$$
\ln \left[\mathrm{p}_{\mathrm{j}} /\left(1-\mathrm{p}_{\mathrm{j}}\right)\right]=\ln \mathrm{O}_{\mathrm{j}}=\alpha+\beta_{1} \mathrm{x}_{1}+\beta_{2 \mathrm{X}_{2}}+\ldots+\beta_{\mathrm{k}} \mathrm{X}_{\mathrm{k}}
$$

where $\mathrm{p}_{\mathrm{j}}$ is the probability of bank stability at location $j, \mathrm{x}_{1} \ldots \mathrm{xk}$ are the explanatory variables, and $\mathrm{O}_{\mathrm{j}}$ is simply the conditional odds of bank stability at location $j$, given the explanatory variables. To avoid problems with spatial autocorrelation, only every third segment is included in the sample, so all observations are separated by $30 \mathrm{~m}$. A total of 508 observations were used in the model.

\section{Results}

The bluff survey found that approximately $31 \%$ of the riverbank was rated as unstable, with the unstable areas primarily located in the central and southern sections of town (Figure 2). The northern section of the River, which is primarily stone ledge and heavily forested, was the most stable area.

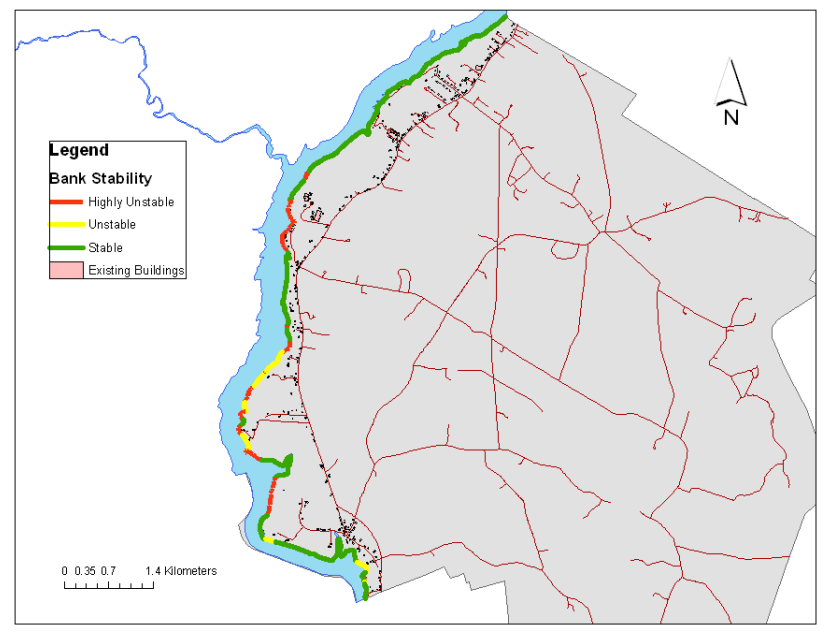

Figure 2: $\quad$ Stability map of Orrington, Maine.

The results of the bank stability model are shown below in Table 1. Overall model fit was assessed with a likelihood ratio chi-squared test $(\alpha=0.05, \mathrm{df}=7$, $\chi^{2}=558.41, \operatorname{Pr}\left[\chi^{2}>\right.$ crit. value $]=0.000$ ) (Hosmer and Lemeshow [3]) and by the Akaike Information Criterion (AIC). Several versions of the model were estimated, with the best-fitting model presented here. Significance of individual parameter estimates was assessed with a Wald statistic test $(\alpha=0.10)$. All 
coefficients are significant and, with the exception of Dev100, have signs consistent with prior expectations.

Table 1: $\quad$ Results of logit model of bank stability.

\begin{tabular}{|l|l|l|l|l|l|}
\hline Variable & Coefficient & $\begin{array}{l}\text { Standard } \\
\text { error }\end{array}$ & P-value & $\begin{array}{l}\text { Marginal } \\
\text { effect }\end{array}$ & $\begin{array}{l}\text { Marginal } \\
\text { effect } \\
\text { P-value }\end{array}$ \\
\hline Intercept & -4.5161 & 0.830372 & 0.0000 & -0.9248 & 0.0000 \\
\hline Slope_max & -0.05275 & 0.016549 & 0.0014 & -0.0108 & 0.0012 \\
\hline Dev100 & 0.050308 & 0.013386 & 0.0002 & 0.0103 & 0.0002 \\
\hline Setback & 0.001031 & 0.000607 & 0.0895 & 0.0002 & 0.0901 \\
\hline Ledge & 1.6491 & 0.254707 & 0.0000 & 0.3593 & 0.0000 \\
\hline Tall_trees & 2.00785 & 0.731684 & 0.0061 & 0.4637 & 0.0012 \\
\hline Hi_dens & 3.20015 & 0.402686 & 0.0000 & 0.6626 & 0.0000 \\
\hline
\end{tabular}

The interpretation of coefficients in logit models is not readily intuitive, but marginal effects provide a convenient alternative. For continuous variables, marginal effects represent the effect of a one unit change in the explanatory variable on the probability of an event, in this case the occurrence of a stable riverbank. Slope max is the maximum slope, as a percent, within 250 feet of the shoreline. Thus the marginal effect of -0.0117 on the variable Slope_max means that a one unit (i.e., one percentage point) increase in Slope max would be expected to decrease the probability of stability by 0.0117 , or by about one percentage point. The negative sign of this coefficient indicates that stability is less likely where there are steep slopes. Dev100 represents the percentage of land within $100 \mathrm{~m}$ of the riverbank that is classified as "developed" on a Maine land cover map (Smith et al. [10]). The variable Dev100 has a positive sign, indicating that riverbanks are more likely to be stable when there is more developed land within $100 \mathrm{~m}$. This surprising result is discussed further in the Discussion section. The positive sign on the variable Setback, which represents the distance from the riverbank to the nearest building, indicates that greater setback distances are correlated with more stable banks.

The remaining variables are from observations of the riverbank recorded as categorical ratings during our field visit. These categorical ratings are represented in the model by dummy variables. For these variables, the marginal effect is the effect of a one unit change (e.g., a change from the condition being false to true) on the dependent variable. Thus, the marginal effect for Ledge, which takes the value of 1 if the bank is stone ledge and 0 otherwise, means that the existence of ledge along the riverbank increases the probability of stability by 0.3593 , or 36 percentage points. The positive signs on Tall_trees and Hi_dens indicate that bank stability is more likely when taller trees $(>6 \mathrm{~m})$ are present, and when vegetation density is high.

\subsection{Predictions of stability after buildout}

To assess the results of future development on bank stability, we used the parameter estimates from the model to predict future bank stability if Orrington's 
shoreline were to be developed at the maximum density possible under current land use zoning laws. Maximum density for each land use zone was estimated and simulated in GIS. Future building locations were buffered by the average size of a residential lawn in Orrington (approximately 2,137 $\mathrm{m}^{2}$ ). The locations of future buildings and yards were then used to recalculate the values of related explanatory variables in order to predict future bank stability following buildout.

Future development would likely affect the values of the Dev100, Setback, Tall trees, and Hi_dens variables. In the buildout scenario, we assumed houses would be built as close as $33 \mathrm{~m}(100 \mathrm{ft})$ from the river -- the minimum setback allowed under Shoreland Zoning. Based on the GIS buildout layer, we recalculated the values of Dev100 and Setback to reflect the increased development and decreased setbacks. Changing these two variables alone (Scenario 1) yielded a prediction that $24 \%$ of the bank would be unstable following buildout. This is a reduction from the current level of $31 \%$, reflecting our finding that increased development had a positive effect on stability in our model, an assumption of which we are dubious.

For Scenario 2 we added the assumption that new landowners would remove large trees along the riverbank in order to improve their view, essentially removing the Tall trees variable from the model. This resulted in a prediction that $53 \%$ of the bank would become unstable. Finally, for Scenario 3 we assumed large trees were left, but vegetation density was reduced so that high vegetation density sections along the riverbank were eliminated. Under this scenario, $92 \%$ of the shoreline was predicted to become unstable. Clearly, many other future development scenarios could be modeled, although these three are likely to capture the range of possibilities.

\section{Discussion}

Our future development scenarios demonstrate how landowner activities are likely to play an important role in riverbank erosion risk. Under our model, the increased development and decreased structural setbacks depicted in Scenario 1 actually reduced the amount of unstable shoreland, as the positive effects of Dev100 outweighed the negative effects of the greater proximity of buildings. Again, we are highly suspicious of the positive relationship between Dev100 and stability, and feel that it primarily reflects historic development in Orrington that was located along stable riverbanks. We do not believe that there is a causal relationship between development and riverbank stability.

Scenarios 2 and 3 suggest larger areas of erosion risk stemming from future development. These predictions are the result of the large marginal effects of the Tall_trees and Hi_dens variables, 0.4637 and 0.6626 , respectively. We are a bit dubious of the effect of Tall_trees, however, as it has been suggested that larger trees may sometimes be problematic since they disturb large areas of riverbank when they do fall, and that tree species may be more important than size. At any rate, bankside vegetation is certainly an important consideration in erosion risk and control (Ott [8]). Our results suggest that efforts to minimize cutting and removal of bankside vegetation would pay large dividends in terms of erosion 
risk. The marginal effect of the variable Setback (0.0002), on the other hand, is relatively small. These results together suggest that bankside vegetation plays a much more important role than structural setbacks in erosion control, and thus may be a more important focus for local regulators.

Land use planners should consider riverbank stability when considering growth and development. Where unstable banks are known to exist, greater setbacks may be appropriate. While we have suggested that setbacks have little effect on stability, they do serve to minimize the likelihood and severity of loss of property and life in case of a major erosion event. Another possibility would be to enact policies that encourage the establishment of open space along shorelines, perhaps through open space set-asides or density bonuses in subdivision ordinances.

\section{Conclusions}

Erosion along the Penobscot River estuary in Orrington, Maine, has already resulted in environmental degradation, property loss, and economic costs to landowners. In extreme cases, property owners have been forced to re-locate homes away from eroding riverbanks, or construct expensive bank stabilization projects. Our modeling demonstrated that many currently undeveloped sections along the River are at-risk for similar events in the future. Given that development pressures along riparian zones will likely continue, increased efforts are needed to assess erosion risk in order to minimize future economic, social, and environmental losses.

While this study addressed erosion risks along Maine's Penobscot River, the methods and results have broad application to other river-front communities. Ideally, erosion prevention and control should involve all municipalities within a watershed, although limited resources and conflicting local policies may limit such cooperation. In any event, the natural interconnectivity of riparian systems and watersheds suggests a greater need for regional approaches to watershed protection in an effort to sustain both social and ecological values.

\section{Acknowledgements}

The authors acknowledge helpful insights and comments from Kathleen Bell, Aram Calhoun, Louis Morin, David Hart, Malcolm Hunter, Jessica Leahy, Chet Rock, Joseph Westphal, and Stephen Yost.

\section{References}

[1] Atkinson, P.M., S.E. German, D.A. Sear, M.J. Clark. Geomophological controls using geographically weighted logistic regression. Geographical Analysis, 35, pp. 58-82, 2000.

[2] Bledsoe, B.P. and C.C. Watson. Logistic analysis of channel pattern thresholds: meandering, braiding, and incising. Geomorphology, 38(3,4), pp. 281-300, 2001. 
[3] Hosmer, D.W. and S. Lemeshow. Applied Logistic Regression. New York: Wiley, 1989.

[4] Kelley, Joseph T. and Stephen M. Dickson. Low-cost bluff stability mapping in coastal Maine: providing geological hazard information without alarming the public. Environmental Geosciences, 7(1), pp. 46-56, 2000.

[5] Maene, L.M. and Wan Sulaiman Wan Harun. Status of soil conservation research in peninsular Malaysia and its future development. Proceedings of the Conference on Soil Science and Agriculture in Development in Malaysia, Malaysian Society of Soil Science, Kuala Lumpur, 1980.

[6] Maine Department of Environmental Protection. Maine Bureau of Land and Water Quality (BLWQ). http://www.maine.gov/dep/blwq.

[7] Orrington Comprehensive Plan. Orrington, Maine.

[8] Ott, Robert A. Factors affecting stream bank and river bank stability, with an emphasis on vegetation influences. Compiled for the Region III Forest Practices Riparian Management Committee. Fairbanks, Alaska. 2000.

[9] Pimentel, David and Nadia Kounang. Ecology of soil erosion in ecosystems. Ecosystems, 1(5), 416-426, 1998.

[10] Smith, M., M. Palmer, and A. Brenner. Landcover development: state/federal collaboration improves data quality, saves money. Earth Imaging Journal, 3, 16-19. 2006.

[11] Stein, Susan M., Ronald E. McRoberts, Ralph J. Alig, Mark D. Nelson, David M. Theobald, Mike Eley, Mike Dechter, and Mary Carr. Forests on the edge: housing development on America's private forests. General Technical Report PNW-GTR-636. Portland, OR: U.S. Department of Agriculture, Forest Service, Pacific Northwest Research Station. 16 p. 2005.

[12] U.S. Bureau of Census. Census of Population and Housing. 2000.

[13] White, Eric M. Forests on the edge: a case study of south-central and southwest Maine watersheds. USDA Forest Service, Pacific Northwest Research Station. 2006.

[14] Winterbottom, S.J. and D.J. Gilvear. A GIS-based approach to mapping probabilities of river bank erosion: regulated River Tummel, Scotland. Regulated Rivers: Research and Management, 16(2), pp. 127-140, 2000. 